Pohl, 1

\title{
When did Robert of Torigni first receive Henry of Huntingdon's Historia Anglorum, and why
}

does it matter?

\section{Benjamin Pohl}

In this article, ${ }^{1}$ I seek to shed new light on a question which, to date, has been little more than a subtle chronological debate amongst historians. Previous studies have left little room for doubt that Robert of Torigni consulted Henry of Huntingdon's Historia Anglorum (referred to hereafter as HA) for the composition of his own magnum opus, the Chronica. ${ }^{2}$ There is, however, much less certainty as to when, precisely, Robert first received a manuscript copy of Henry's work at the monastery of Le Bec in Normandy. Was it in 1139, the year in which Henry temporarily ceased his work in order to accompany Archbishop Theobald of Canterbury on a mission to the European mainland? Or was it several years later, when Henry had long since resumed his work on the $H A$, causing it to evolve into an even more substantial historical narrative? And why does it matter? Finding an answer to these questions - however esoteric they might at first appear - promises to produce knowledge of which the significance extends beyond the intertextual relationship between Henry's $H A$ and Robert's Chronica. By identifying the precise dynamics of Robert's interaction with Henry, as well as the logistics and channels of communication which connected the two historians and their works, I aim to offer an innovative lens through which to investigate similar texts and contexts in a wider chronological and geographical framework. 'Intertextuality', in this context, will be showcased not merely as a theoretical, but rather as a practical concept for the study of medieval historiography.

I commence this study by challenging the prevailing notion that Robert was presented with a copy of the $H A$ as early as 1139 . Instead, I produce evidence to suggest a later date, one closer to Robert's appointment as prior of Le Bec in $1149 .{ }^{3}$ My argument consists of three strands, represented here as three thematic sections. Each of these sections focuses on a separate yet related piece of

\footnotetext{
${ }^{1}$ This article is based on my research paper 'There and Back Again: Scribal Correspondence and Manuscript Exchange between the Abbey of Le Bec and Its Neighbours (The Case of Henry of Huntingdon and Robert of Torigni)', held at the International Congress of Medieval Studies in Leeds on 2 July 2013 in a session cosponsored by the Haskins Society and the Battle Conference for Anglo-Norman Studies. In revising this paper for publication, I am particularly indebted to the helpful suggestions of Anne Duggan, Michael Gelting, Robert Berkhofer III and Jaakko Tahkokallio. I would also like to express my gratitude to Thomas Bisson for sharing with me his detailed knowledge about the manuscripts of Robert's Chronica. Work on this article was supported by a postdoctoral fellowship of the German Academic Exchange Service (DAAD), as well as by the Neil Ker Memorial Fund (British Academy).

2 A brief survey of Robert's relationship with Henry and his HA is provided in Henry, Archdeacon of Huntingdon: Historia Anglorum (The History of the English People), ed. D. E. Greenway, Oxford Medieval Texts (Oxford, 1996), pp. lxi, lxxii-v. A more detailed case study has been conducted on these matters by D. Bates, 'Robert of Torigni and the Historia Anglorum', in The English and their Legacy, 900-1200: Essays in Honour of Ann Williams, ed. D. Roffe (Woodbridge, 2012), pp. 175-84.

${ }^{3}$ On Robert's biography, see Chronique de Robert of Torigni: Abbé du Mont-Saint-Michel, ed. L. Delisle, 2 vols. (Rouen, 1872-3), II, i-xiii; The Gesta Normannorum Ducum of William of Jumièges, Orderic Vitalis, and Robert of Torigni, ed. E. M. C. van Houts, Oxford Medieval Texts, 2 vols. (Oxford, 1992-5), I, lxxvii-ix; D. Dumville, 'An Early Text of Geoffrey of Monmouth's Historia Regum Britanniae and the Circulation of some Latin Histories in Twelfth-Century Normandy', Arthurian Literature 4 (1984), 1-36 (p. 30). Also cf. E. M. C. van Houts, 'Robert of Torigni as Genealogist', in Studies in Medieval History: Presented to R. Allen Brown, ed. C. Harper-Bill, C. J. Holdsworth and J. L. Nelson (Woodbridge, 1989), pp. 215-34.
} 
evidence which previous scholarship has considered indicative of an earlier date of composition than the one argued for in this article. First, I analyse and compare different narrative accounts which testify to Robert's involvement with the $H A$. I then turn directly to the medieval manuscript tradition in order to develop a clearer notion as to which version or redaction of the text Robert is likely to have used for the composition of his Chronica. ${ }^{4}$ Finally, I reassess the place of the $H A$ within the monastic library of Le Bec during the twelfth century. Prior to commencing this line of enquiry, however, I must briefly recapitulate the argument for dating as it stands today.

Generally speaking, scholarly consensus has it that Robert was first presented with a manuscript copy of the $H A$ in 1139 , the very year when Henry travelled to Le Bec in the company of Archbishop Theobald and, allegedly, showed Robert a manuscript containing his work-in-progress. ${ }^{5}$ Scholars hypothesise that Henry granted Robert access to his working copy of the $H A$ as an act of reciprocity, in return for being presented with a copy of Geoffrey of Monmouth's Historia regum Britanniae (referred to hereafter as HRB). Following David Dumville's assessment of the HRB's manuscript tradition in Normandy, an exemplar of Geoffrey's work had probably arrived at Le Bec shortly before Henry's visit, where it was copied and integrated into the abbey's book collection, possibly at Robert's request. ${ }^{6}$ I will discuss the details of this meeting and alleged exchange of manuscripts at greater length below. Henry's visit to Le Bec is well documented, both in the $H A$ and in Robert's Chronica. What seems to have given rise to the occasion, in the first instance, was Archbishop Theobald's journey to Rome via Normandy in 1139. Before his investment as the Archbishop of Canterbury (1138-61), Theobald had been Abbot of Le Bec (1137-8). Besides diplomatic reasons, Henry's agreement to accompany Theobald to Le Bec appears to have been informed by the historian's pronounced interest in 'Norman matters'. During the late 1130s, Henry was busy with gathering supplementary material for his $H A$, the first books of which he had completed in or around $1131 .^{7}$ As Diana Greenway has shown conclusively, the composition of the HA was a continuous and long-winded process, spanning several decades and producing various subsequent versions (or redactions) of the text. ${ }^{8}$ In 1139 , the $H A$ was still at an intermediate stage of its composition, at which point Henry surely appreciated - and in some cases sought - new source

\footnotetext{
${ }_{5}^{4} H A$, ed. Greenway, p. lxvii.

5 This theory first appears in an article by F. Liebermann, 'Heinrich von Huntingdon', Forschungen zur deutschen Geschichte 18 (1878), 265-95. It gained momentum about a century later when reinvigorated by Dumville, 'Early Text', pp. 31-32. Also cf. N. Wright, 'The Place of Henry of Huntingdon's Epistola ad Warinum in the Text-History of Geoffrey of Monmouth's Historia Regum Britannie: A Preliminary Investigation', in France and the British Isles in the Middle Ages and Renaissance: Essays in Memory of Ruth Morgan, ed. G. Jondorf and D. N. Dumville (Woodbridge, 1991), pp. 71-114; GND, ed. van Houts, I, lxxviii. Greenway initially opts for a more careful treatment of the subject, but finally seems to admit the overall persuasiveness of Dumville's argument; see HA, ed. Greenway, pp. lxxii-iii. More recently, David Bates has expressed justified scepticism, observing that '[t]his argument for an earlier dating [i.e. c.1139] cannot be verified textually'; see Bates, 'Robert of Torigni', p. 178.

${ }^{6}$ Dumville, 'Early Text', pp. 4-16. On Robert's monastic career and his involvement in the acquisition and production of books, see my article B. Pohl, 'Abbas qui et scriptor? The Handwriting of Robert of Torigni and his Scribal Activity as Abbot of Mont-Saint-Michel (1154-1186)', Traditio 69 (2014, forthcoming).

${ }^{7} H A$, ed. Greenway, p. lxx.

${ }^{8}$ Ibid., pp. lxvi-xxvii.
} 
material to be incorporated into the ever-growing narrative. It is not impossible that Henry was hoping to find some books at Le Bec which at that time were not, or perhaps not yet, available in England (Geoffrey's $H R B$ being one of them). What is of particular interest to the present study, however, are not so much the books which Henry might have seen during his visit to Normandy in 1139, but rather those which he might or might not have carried with him on that journey.

Narrative accounts: the Historia Anglorum, the Chronica and the Epistola ad Warinum

The first piece of evidence to be reviewed here is Henry's own account of his visit to Le Bec in 1139 . Perhaps the single most important source testifying to this event is a letter which, having been written after Henry's return to England, later came to feature in Book Eight of the HA. This letter, which Henry addresses to a certain Warin (the Breton), is known to scholars as the Epistola ad Warinum (referred to hereafter as $E A W) .{ }^{9}$ Essentially, the $E A W$ contains a heavily-abridged summary of Geoffrey's $H R B$, which Henry claims to have excerpted from a book which he consulted at Le Bec. Sure enough, the EAW provides an ex post facto account of the events of 1139 . It only entered the $H A$ 's narrative as part of a later revision produced either in or shortly after 1140 (corresponding to Greenway's Version 3) or even as late as 1146 (Version 4). ${ }^{10}$ At the outset of the letter, Henry relates how

[t]his year, when I was on way to Rome, to my amazement I discovered, at the abbey of Le Bec, a written account of those very matters. Of this I send you, dear friend, some excerpts, much shortened so as to fit into a letter (Hoc tamen anno, cum Romam proficiscerer, apud Beccensem abbatiam scripta rerum predictarum stupens inveni. Quorum excerpta, ut in epistola decet, brevissime scilicet, tibi dilectissime mitto). ${ }^{11}$

The 'matters' (rei) referred to by Henry can easily be identified with stories about the ancient kingdoms said to have flourished in the British Isles before the Roman invasions under Julius Caesar (florentissima regna, que a Bruto usque ad tempus Iulii fuerunt). ${ }^{12}$ Evidently Henry, during the years prior to his visit, had been trying to obtain a reliable narrative source for the history of pre-Roman Britain, with which he was seeking to preface the events already related in his $H A$. It is tempting indeed to imagine Henry searching not only the great library of Lincoln Cathedral for information on the subject, but perhaps also the book collections of other institutions in its vicinity, such as Ely Cathedral or the monastic communities at Crowland and Thorney. Ultimately, however, he must have

\footnotetext{
${ }^{9}$ Ibid., pp. 558-83.

${ }^{10}$ Ibid., pp. lxx-xxi. Bates, 'Robert of Torigni', p. 177 suggests that Robert copied the EAW (or rather parts thereof) during the $1150 \mathrm{~s}$, which, theoretically, would allow for either date of composition.

${ }^{11} H A$, ed. Greenway, p. 558.

${ }^{12}$ Ibid.
} 
been frustrated by the meagre result. ${ }^{13}$ Just how great must have been Henry's joy and amazement upon finally discovering a copy of the $H R B$ at Le Bec - an event which he reports in the most animated words to his friend Warin.

Still, however, Henry's description of his visit to Le Bec in 1139 is comparatively brief and does not offer a lot of detail. The majority of the $E A W$ is dedicated to the content which Henry extracted from Geoffrey's $H R B$, rather than with the story of how he gained access to it in the first place. This changed considerably when Robert later copied the $E A W$ (as an incorporated part of the HA) into his Chronica. What is particularly important is the number of changes implemented by Robert whilst copying Henry's letter. First and foremost, Robert's version of the $E A W$ includes additional details such as, for example, the precise date of Henry's visit. In Henry's original version of the $E A W / H A$, the date is simply given as hoc tamen anno, thus leaving it to the reader to deduce the exact year from the narrative's chronological context. ${ }^{14}$ Robert, by contrast, provides the precise year, whilst also including his own name and personal involvement in the matter:

This year, when I was on way to Rome with Archbishop Theobald of Canterbury, that is, in the 1139th year after the incarnation of our Lord, to my amazement I discovered, at Le Bec, where the same archbishop used to be abbot, a written account of those matters. Indeed, there I met with Robert of Torigni, the then abbot of that place, a man most devoted to the investigation and collection of both divine and secular writings, who - having enquired about the series of the 'History of the English Kings' which I had published, and gladly listening to what he had asked me about - presented me with a book about the kings of Britain, so I could read it. Of this I send you, dear friend, some excerpts, much shortened so as to fit into a letter (Hoc tamen anno, qui est ab incarnatione Domini M C XXX nonus, cum Romam proficiscerer cum Theobaldo Cantuariensi archiepiscopo, apud Beccum, ubi idem archiepiscopus abbas fuerat, scripta rerum predictarum stupens inveni. Siquidem Robertum de Torinneio, eiusdem loci monachum, virum tam divinorum quam secularium librorum inquisitorem et coacervatorem studiosissimum, ibidem conveni. Qui cum de ordine hystoriae de regibus Anglorum a me editae me interrogaret, et id quod a me quaerebat libens audisset, obtulit michi librum ad legendum de regibus Britonum, qui ante Anglos nostrum insulam tenuerunt; quorum excerpta, ut in epistola decet, brevissime scilicet, tibi dilectissime mitto). ${ }^{15}$

What is important here is that Robert neither assumes authorship over the passage nor declares his having subsequently added to it. Rather than reserving narrative authority for his own person - as, of course, he could have done simply by referring the reader to his first-hand recollection as an

\footnotetext{
${ }^{13}$ On the circulation of Geoffrey's Historia in Anglo-Norman England and the distribution of its manuscripts, see Wright, 'Epistola ad Warinum', pp. 76-8. Also cf. Dumville, 'Early Text', pp. 15-22. Yet more comprehensive is the manuscript study provided by J. Crick, The Historia regum Britannie of Geoffrey of Monmouth: A Summary Catalogue of the Manuscripts (Woodbridge, 1989).

${ }^{14}$ Wright, 'Epistola ad Warinum', p. 74.

${ }^{15}$ Chronique, ed. Deslisle, I, 97.
} 
'eyewitness' to the events of 1139 -, Robert instead introduces a rubric which unmistakably identifies the passage as a copy of the letter originally written by Henry (Incipit epistola Henrici archidiacono ad Warinum de regibus Britonum). ${ }^{16}$

Robert's decision to rely on Henry's authority explicitly, rather than on the weight carried by his own recollection of the events of 1139 , is interesting for several reasons. First, it seems to betray a preference for the written word over oral testimony, despite the fact that Robert's word would not have been common hearsay, rather an account from his personal memory. ${ }^{17}$ More specifically, though, the verbatim insertion of the $E A W$ into the Chronica allows Robert to locate his own chronicle more firmly within an already established canon of historical writings. Last but not least, it serves to emphasise Robert's own importance, both as an historian and as an integral and influential member of the monastic community of Le Bec. It is the last point which becomes particularly obvious when comparing the two versions of the 1139 encounter. Indeed, it is only with Robert's redaction and expansion of the $E A W$ that we first learn of his personal involvement in the matter. In Henry's original version of the $E A W$, no mention is made of Robert whatsoever. Of course, Henry's silence concerning Robert must not mean that the latter took no part in arranging and preparing the visit in 1139. It remains perfectly possible that it was indeed Robert who guided Henry around the abbey's library and fetched the copy of Geoffrey's HRB upon his visitor's request. After all, Robert would have been intimately familiar with Le Bec's book collection due to both his own activity as a historian and the role he appears to have played in the acquisition and cataloguing of books. ${ }^{18}$ It was also precisely around that time that Robert is thought to have finished the first draft of his redaction of William of Jumièges' Gesta Normannorum ducum (referred to hereafter as GND), though he did continue to make small amendments to it for another twenty years or so thereafter. ${ }^{19}$ Still, if Robert had played at least some part in the events of 1139 , it remains curious that Henry would not mention Robert at all in his original version of the $E A W$.

\footnotetext{
${ }^{16}$ Ibid. Copying letters into historiographical works was, of course, a common technique amongst medieval historians. This can be seen, for example, in the writings of the Venerable Bede, whose Historia ecclesiastica gentis Anglorum continued to provide a model for later generations of Anglo-Norman historians, including Henry. See D. E. Greenway, 'Henry of Huntingdon and Bede', in L'historiographie médiévale en Europe: Actes du colloque organisé par la Fondation Européenne de la Science au Centre de Recherches Historiques et Juridiques de l'Université Paris I du 29 mars au ler avril 1989, ed. J.-P. Genet (Paris, 1991), pp. 43-50 ; R. H. C. Davis, 'Bede after Bede', in Studies in Medieval History: Presented to R. Allen Brown, ed. C. Harper-Bill, C. J. Holdsworth and J. L. Nelson (Woodbridge, 1989), pp. 103-16; A. Gransden, 'Bede's Reputation as an Historian in Medieval England', in Legends, Tradition and History in Medieval England, ed. A. Gransden (London, 1992), pp. 1-30.

${ }^{17}$ On medieval discourses about the relationship between oral and written testimony, see M. Mostert, 'The Memory of Writing: Thoughts about How the Introduction of Written Culture Restructured Memory in the Middle Ages', in Erfahren, Erzählen, Erinnern: Narrative Konstruktionen von Gedächtnis und Generation in Antike und Mittelalter, ed. H. Brandt, B. Pohl et alii, Bamberger Historische Studien 9 (Bamberg, 2012), pp. 1558. Also cf. M. T. Clanchy, 'Introduction', in New Approaches to Medieval Communication, ed. M. Mostert, Utrecht Studies in Medieval Literacy 1 (Turnhout, 1999), pp. 3-14; M. T. Clanchy, From Memory to Written Record: England 1066-1307, 3rd edn (Oxford, 2012).

${ }^{18}$ G. Nortier, Les bibliothèques médiévales des abbayes bénédictines de normandie: Fecamp, Le Bec, Le Mont Saint-Michel, Saint-Évroul, Lyre, Jumièges, Saint-Wandrille, Saint-Ouen, 2nd edn (Paris, 1971), p. 39.

${ }^{19} G N D$, ed. van Houts, I, lxxix-x. Also cf. Wright, 'Epistola ad Warinum', p. 72.
} 
Whether or not Robert had actually embarked on his next and even more ambitious writing project by the time Henry visited Le Bec in 1139 - the compilation of his Chronica -, there is "no reason to dismiss the notion that he already had some sort of larger project in mind. ${ }^{20}$ If Robert. upon hearing of Henry's forthcoming visit to Normandy, had already set his mind on writing a chronicle which included not only Norman but also English history, as is argued compellingly by Bates, he probably would have made sure to be involved personally in welcoming the English historian within the walls of his home monastery. He might even have gone so far as to prepare a selection of books from Le Bec's library for Henry to look at whilst there, perhaps to facilitate an exchange of knowledge about some of the more recent events in English history. What is certain, meanwhile, is that the excitement with which Henry relates the discovery of the $H R B$ in the $E A W$ stands in stark contrast to his complete silence concerning the man who supposedly granted him access to Geoffrey's work in the first place. Of course, Henry's preoccupation probably remained with the HRB's value as a source for the $H A$, rather than with the exact history of its acquisition. Still, it is difficult to reconcile Henry's version of the $E A W$ in accordance with the later additions made by Robert. This is true particularly with regard to Robert's self-flattery in relation to his own habit of collecting and acquiring books on behalf of his community, which, contrary to Henry's original report, seems to confirm that Robert assumed a prominent position at Le Bec long before his appointment as prior in $1149 .{ }^{21}$ As I have argued elsewhere, during this early period of his monastic career at Le Bec, Robert might already have fulfilled a role not dissimilar to that of an armarius or precentor, which would certainly have made him responsible for the abbey's library and scriptorium. ${ }^{22}$ Scholars have suspected Robert's personal influence behind several of Le Bec's greatest literary and bibliographical achievements, including the compilation of its surviving mid-twelfth-century library catalogue, to which I shall return below. ${ }^{23}$ However, there is so far surprisingly little concrete evidence to place Robert at the helm of the events of 1139 .

Apart from Robert's later redaction of the $E A W$, there is no further evidence to suggest that Henry's copying the HRB in 1139 was part of a reciprocal act between two colleagues and fellowhistorians, assisting each other with their respective projects. Nowhere in the $H A$ do we learn anything about a mutual exchange of manuscripts. It is Robert alone who insists that Henry was granted access to Le Bec's copy of Geoffrey's work only after he, in complying with his host's wish, had provided information concerning his own chronicle, the 'history of the English kings' (cum de ordine hystoriae de regibus Anglorum a me editae me interrogaret, et id quod a me quaerebat libens audisset). The

\footnotetext{
${ }^{20}$ Bates, 'Robert of Torigni', p. 117.

${ }^{21}$ Chronique, ed. Delisle, I, 97: Siquidem Robertum de Torinneio, eiusdem loci monachum, virum tam divinorum quam secularium librorum inquisitorem et coacervatorem studiosissimum, ibidem conveni.

${ }^{22}$ Pohl, 'Abbas qui et scriptor?'.

${ }^{23}$ R. H. Rouse and M. A. Rouse, "'Potens in opere et sermone": Philip, Bishop of Bayeux, and His Books', in Authentic Witnesses: Approaches to Medieval Texts and Manuscripts, ed. R. H. Rouse and M. A. Rouse, Publications in Medieval Studies (Notre Dame, IN, 1991), pp. 323-59, at p. 323; P. Stirnemann, 'Two TwelfthCentury Bibliophiles and Henry of Huntingdon's Historia Anglorum', Viator 24 (1993), 121-42.
} 
specific Latin phrasing used by Robert here is significant; arguably, it could actually indicate that the information which Robert claims to have received from Henry in 1139 was in fact in oral form, rather than written, which is, of course, the diametric opposite of that which is usually assumed. Both Henry and Robert are, after all, explicit in referring to the 'mediality' of Geoffrey's HRB: Henry refers to it collectively, that is, as a plural noun, 'writings of matters previously mentioned' (scripta rerum predictarum) ${ }^{24}$ Robert is somewhat more specific, going so far as to call it a book (librum), which he produced for Henry to read (ad legendum) ${ }^{25}$ The $H A$, by contrast, is not described in similarly specific terms; in fact, all we really learn from Robert's account is that he enquired (interrogaret) about the work, and that Henry was happy to answer Robert's enquiry (quod a me quaerebat). A key clue to this having happened in oral form might be that Robert says he had 'gladly listened' (libens audisset) to what Henry told him, thereby referring to an oral exchange of information (at least on Henry's part), rather than a mutual exchange of writings. As we saw earlier in the customised rubric which introduced Robert's redaction of the $E A W$, Robert was careful to distinguish explicitly between oral and written sources (whilst revealing a general preference for the latter). It is possibly revealing, therefore, that Robert should refer to the $H R B$ as a librum, but not be similarly precise about the information which he received from Henry concerning the kings of the English. Perhaps, indeed, he sought to intimate that the latter was indeed received verbally, rather than in writing.

What is more, such a revised reading of the $E A W$ (that is, of Robert's redaction thereof) also enables us better to explain the figurative content of a large historiated initial in what is known as the 'working copy' of Robert's Chronica, produced at Mont-Saint-Michel during the second half of the twelfth century (Avranches, Bibliothèque Municipale MS 159). ${ }^{26}$ Preserving the Chronica in what must be considered an advanced - if not indeed the final - stage of its composition, Avranches 159 was produced under Robert's personal supervision after he had left Le Bec in 1154 to become abbot of Mont-Saint-Michel. ${ }^{27}$ Even though the copy of the Chronica contained in Avranches 159, ff. 169r$236 \mathrm{v}$ is largely the work of a team of scribes, rather than Robert's autograph, the historian's own hand can be identified in a series of corrections and interlinear glosses which attest to his first-hand familiarity with the manuscript and show his personal involvement in its publication. ${ }^{28}$ In Avranches 159 , the $E A W$ features on ff. $174 \mathrm{v}-78 \mathrm{v}$, and the redaction thereof is naturally Robert's rather than Henry's. ${ }^{29}$ It is presented as part of Robert's continuation of the Chronicle of Sigebert of Gembloux,

\footnotetext{
${ }^{24} H A$, ed. Greenway, p. 558.

${ }^{25}$ Chronique, ed. Delisle, I, 97.

${ }^{26}$ For a description of this manuscript, see Ibid., pp. xlv-liii. Also cf. Pohl, 'Abbas qui et scriptor?'.

${ }^{27}$ P. J. Geary, Living with the Dead in the Middle Ages (Ithaca, 1994), p. 249 argues that Avranches 159 'can be considered the author's [i.e. Robert's] final edition, and it continues until the year 1185'. Also cf. Chronique, ed. Delisle, I, xliii, who argues that the Chronica's final stage of composition might be represented by Cambridge, University Library MS Ff.I.31: '[le manuscrit] nous offre le texte de la Chronique de Robert sous la dernière forme que l'auteur lui donna'.

${ }^{28}$ See Pohl, 'Abbas qui et scriptor?'.

${ }^{29}$ Other historical works appearing in the same manuscript include the histories of Eusebe, Jerome and Prosper of Aquitaine; cf. Chronique, ed. Delisle, I, xlvi-ix.
} 
rather than as a separate text. ${ }^{30}$ On f. $174 \mathrm{v}$, the EAW's opening word Queris ('you [Warin] ask') is decorated with a large historiated initial of the letter 'Q', incorporating at its centre two pictorial scenes which show two men engaged in conversation (fig. 1). Given the narrative context of the initial as well as its specific location within the mise en page, these two men are commonly held by scholars to represent Robert and Henry on the occasion of Henry's visit to Le Bec in 1139. Neil Wright, whilst admitting the initial's ambivalent iconography, surmises that it shows 'Robert discussing Henry of Huntingdon's Historia Anglorum with its author, and, below, presenting the "amazed" Henry with Geoffrey of Monmouth's Historia regum Britanniae. ${ }^{31}$

Upon first glance, the illumination appears to support such an interpretation: located directly beneath a frieze featuring the busts of what appear to be three crowned kings, ${ }^{32}$ the first of the two scenes shows two male figures who are engaged in conversation, their hands gesticulating. The figure sitting to the right and dressed in a green robe has tonsured hair, and is thus more likely to depict Robert, as Henry was part of the secular clergy and did not have to wear a tonsure (meaning that he is probably represented by the figure in red sitting to the left). Placed in the middle and resting on a pedestal or reading desk we can see an open book, which Wright interprets as the $H A$ and tentatively identifies as the subject matter of Robert and Henry's conversation. Yet, as I have argued above, the passage from the $E A W$ corresponding to the initial in Avranches 159, f. $174 \mathrm{v}$ does not describe the $H A$ as a book (librum), rather as the subject matter of an oral conversation taking place between Henry and Robert. Additionally, the book's orientation, with its pointy lower end aimed at Henry, rather than Robert, could suggest that it is being directed towards Henry's reading it. ${ }^{33}$ Robert's right hand, stretched out demonstratively over the open book as if to explain its content to Henry, appears to have been conceptualised as a direct figurative realisation of one of the Latin sentences inserted by Robert into the EAW, obtulit michi librum ad legendum de regibus Britonum ('he [Robert] presented me [Henry] with a book about the kings of Britain, so I could read it'). ${ }^{34}$ Had it been meant to represent the $H A$, it is arguable that the book would have been shown as facing the opposite direction, with Henry explaining the content of his own work to Robert, rather than vice versa.

In the second scene, the two figures have switched sides. It is Robert (again, the tonsured figure in green) who upon entering the initial from the left is shown to hand over a book to Henry, who is already waiting to the right, leaning forward on bended knee and with arms wide open in anticipation of the book he is about to receive. The book here seems to be the same one depicted above, namely Le Bec's in-house copy of the $H R B$ which Robert might have helped to obtain. When

\footnotetext{
${ }^{30}$ On Sigebert's 'Universal Chronicle' and its conception of history, see M. Chazan, L'Empire et l'histoire universelle de Sigebert de Gembloux à Jean de Saint-Victor XIIe-XIVe siècle (Paris, 1999).

${ }^{31}$ Wright, 'Epistola ad Warinum', p. 73.

${ }^{32}$ These three busts, which are accompanied by six more of the same kind, located around either side of the ' $Q$ ' in sets of three, probably represent the rulers of pre-Roman Britain, the reigns of whom form the subject matter of the $H R B$ and, in abridged form, the $E A W$.

${ }^{33}$ The orientation of the book shown directly below (in the second scene) supports such an interpretation.

${ }^{34}$ Chronique, ed. Delisle, I, 97.
} 
interpreted in such a way, the first scene no longer depicts a conversation separate from that in the second scene, but rather its prelude: having explained the $H R B$ 's content to Henry, Robert then hands the book over to Henry, presumably so he can copy it. Finally, the iconographic posture of the two figures and their dramatic body language serve to emphasise further Robert's dominant role in the depicted scene. We should note that in both cases it is he who is playing the active part, first by drawing upon his erudition as a collector and acquirer of books (librorum inquisitorem et coacervatorem studiosissimum) to outline the HRB's narrative content, and then, in the second scene, by actually bestowing the book upon Henry. Such a depiction, moreover, would be entirely in line with the agenda argued for above as possibly having governed Robert's reworking of the $E A W$, namely to emphasise his own standing within Le Bec's monastic hierarchy during the late 1130s. Given that the scribes and illuminators responsible for producing Avranches 159 at Mont-Saint-Michel were working under Robert's direct personal supervision, perhaps in the capacity of amanuenses, such an intrinsic relationship between text and image becomes all the more plausible.

The manuscripts of the $H A$

As could be demonstrated above, careful linguistic analysis of Robert's redaction of the EAW combined with a re-evaluation of the figurative illumination it received in Avranches 159 permits us to cast justified doubts on the established notion that Henry presented Robert with a manuscript copy of the $H A$ as early as 1139 . The longevity and persistence of this theory amongst scholars has much to do with how the surviving manuscript evidence has been interpreted. It is necessary, therefore, to reassess some aspects of the $H A$ 's manuscript tradition in the light of the structure of its composition.

As I demonstrated above, Robert does not try to conceal the fact that he used Henry's $H A$ in composing his Chronica. Rather, he explicitly draws upon the authority associated with Henry's oeuvre in order to endow his own writing with a sense of credibility. Moreover, by copying the EAW verbatim and attributing it to Henry (even after making significant amendments), he also adds an air of legitimacy. Similarly, in the prologue of the Chronica, Robert frankly informs his readers about the main sources and literary models which he used for the work's composition. ${ }^{35}$ Besides writers such as Eusebe and the Venerable Bede, we find Robert's primary source of information for the period up to the second decade of the twelfth century to be Sigebert of Gembloux. ${ }^{36}$ Beyond Sigebert, Robert also

\footnotetext{
${ }^{35}$ Chronique, ed. Delisle, I, 91-7.

${ }^{36}$ On Sigebert's oeuvre, see T. Licht, Untersuchungen zum biographischen Werk Sigeberts von Gembloux (Heidelberg, 2005). Sigebert's narrative terminates in 1111, as Robert mentions in his prologue; see Chronique, ed. Delisle, I, 96: Igitur, sicut iam dictum est, quia praedictus Sigisbertus cronica sua incepit ab anno incarnationis dominicae $C C C^{o} L X X X^{o} I^{o}$, et perduxit ea usque ad annum eiusdem divinae incarnationis $M^{u m} C^{u m}$, ego exinde, permittente et auxiliante Deo, sine quo nichil possumus facere, usque ad Mum $C^{u m} L_{X X X}^{u m} I^{u m}$ annum, ea quae in diversis provinciis, et maxime in Normannia et Anglia, evenerunt et ad meam noticiam pervenerunt, sub annis dominicae incarnationis colligere aggrediar.
} 
explicitly indebts himself to the work of William of Jumièges, whose GND he redacted following similar attempts by Orderic Vitalis. Yet, Robert also makes reference to another source, namely

the history by the aforementioned Archdeacon Henry, which he composed concerning the kings of England, beginning with Julius Caesar and carefully continuing until the death of the aforementioned King Henry [I], that is, until the $1135^{\text {th }}$ year after the incarnation of the Lord (historia praedicti Henrici archidiaconi, quam composuit de regibus Angliae, incipiens eam a Iulio Caesare, et texens ordinatim usque ad mortem praedicti regis Henrici, id est usque ad millesimum centesimum tricesimum quintum annum dominicae incarnationis). ${ }^{37}$

Dumville has taken this statement as evidence that Robert must have received a copy of the $H A$ in which the chronological narrative terminated in 1135 (the date given in the Chronica's prologue), thereby tentatively expanding the date for the composition of the Chronica so as to range from the mid-to-late 1130 s to the early $1150 \mathrm{~s} .{ }^{38}$ More recently, however, scholars have expressed doubts concerning the likelihood for such an early time frame, often by reference to an observation which Dumville himself put forward, namely that 'the earliest surviving text of the Chronicle rests on a recension created in $1147 \times 1150 .{ }^{39}$

What prima facie seems to support Dumville's argument concerning the version of the $H A$ used for Robert's Chronica is a colophon for the year 1135 which occurs in some of the HA's later redactions (commencing with Greenway's Version 3). Today, this colophon survives in a total of eleven manuscripts, seven of which date to the twelfth and early thirteenth centuries (see Appendix). ${ }^{40}$ One of these is Cambridge, Corpus Christi College MS 280, which is an English manuscript. Here, the colophon can be found on f. 6r, reading:

Here begins the prologue of the History of the English, composed by Archdeacon Henry of Huntingdon in the year of Grace 1135 (Incipit prologus historiae Anglorum contexte ab Henrico Huntindonensi archidiacono anno gratiae $\left.m^{o} c^{o} x x x^{o} v^{o}\right)$.

Similar versions of the 1135 colophon appear in, for example, in Cambridge, University Library MS Gg.ii.21, f. 3r (Incipit [...] anno gratiae millesimo centesimo $x x x$ v) and Cambridge, University Library MS Ii.ii.3, f. 147r (Incipit [...] anno gratiae $m^{o} c^{o} x x x^{o}$ quinto) (figs. $2 \&$ 3). Indeed, Felix Liebermann used these colophons to argue for a separate redaction of the $H A$ produced in, or at least terminating its narrative with, the year $1135 .^{41}$ Greenway has since refuted this idea, demonstrating that none of the extant manuscripts actually terminate their chronological narrative in that year (rather

\footnotetext{
${ }^{37}$ Ibid., p. 97.

${ }^{38}$ Dumville, 'Early Text', p. 32.

${ }^{39}$ Ibid. This observation is emphasised in $H A$, ed. Greenway, p. lxi and Bates, 'Robert of Torigni', pp. 177-78.

${ }^{40}$ On the colophon, see $H A$, ed. Greenway, pp. 1xx-xxv; D. E. Greenway, 'Henry of Huntingdon and the Manuscripts of his Historia Anglorum', Anglo-Norman Studies 9 (1987), 103-26, at p. 109.

${ }^{41}$ Liebermann, 'Heinrich von Huntingdon', pp. 265-95.
} 
in later years). ${ }^{42}$ Besides Cambridge CCC 280, London, British Library MS Additional 24061 and London, British Library MS Egerton 3668 are the only other copies of the HA to feature the 1135 colophon which belong to what Greenway identifies as Version 3, composed in or shortly after 1140 and based on a now-lost archetype ' $\alpha$ '. ${ }^{43}$ All the other copies belong to later versions of the text, with seven examples of Version 4 and one of Version $6 .{ }^{44}$

When visiting Le Bec in 1139, Henry cannot have carried with him a manuscript resembling either of the two versions with the 1135 colophon quoted above, especially given that Version 3 - the earliest redaction of the $H A$ known to include such a colophon - also features the $E A W$, which, as we have seen earlier, was incorporated after Henry's return to England around 1140 (see, for example, Cambridge CCC 280, f. 156r). This is corroborated by Greenway's observation that not one of the eleven manuscripts which include the 1135 colophon actually terminates its chronological narrative in that year: in fact, three of them end the narrative in 1138 (version 3), seven in 1146 (version 4) and one as late as 1154 (version 6). ${ }^{45}$ In all three cases, the 1135 colophon seems to represent an anachronistic reference; it is not impossible that its obscure origins might lie in an earlier draft version of the text which Henry wrote in or around 1135 but perhaps never intended to be published. ${ }^{46}$ Evidently, neither Henry nor his copyists were particularly rigorous in updating the colophons between subsequent redactions of the $H A$ in keeping with the continuing nature of the text. The majority of the manuscripts belonging to Version 4, despite continuing the narrative as far as the year 1146, still maintain the colophon for 1135 . Even in cases where adjustments were made, the colophons barely (if ever) match the end of the chronological narrative (see Appendix). The manuscripts of Version 5 continue the $H A$ to 1149 , whereas their colophons all date to 1145 or, in the single case of Cambridge, St. John's College MS 184, to 1146. Similarly, Version 6 extends its narrative as far as 1154, but reveals colophons dating to either 1135 (Cambridge Ii.ii.3) or, in the majority of cases, 1145 (Cambridge, University Library MS Dd.i.17; Edinburgh, National Library of Scotland, Advocates' MS 33.5.2; London, British Library MS Arundel 46; London, British Library MS Royal 13 B vi; and Oxford, Bodleian Library MS 521). Generally speaking, therefore, adjusting the dated colophons as the composition of the narrative progressed seems to have been the exception, rather than the rule. This means that the 1135 colophon holds little weight as a reliable determiner of what specific version of the $H A$ Robert might have first received, let alone of when he received it.

Consequently, when Robert in the prologue of his Chronica claims to have used a manuscript of the HA which was contexte [...] anno gratiae $m^{o} c^{o} x x x^{o} v^{o}$, this should in no way be considered

\footnotetext{
${ }^{42}$ Greenway, 'Manuscripts', p. 109.

${ }^{43}$ See $H A$, ed. Greenway, p. lxx and the manuscript stemma in ibid., p. cxviii.

${ }^{44}$ Greenway, 'Manuscripts', pp. 122-23.

${ }^{45}$ Ibid. Also cf. the updated data in $H A$, ed. Greenway, pp. cxix-cxliv.

${ }^{46}$ As Richard Sharpe has demonstrated in his study on the works of Anselm of Canterbury, such 'unofficial' drafts were sometimes disseminated without the author's consent, and despite their unfinished state of composition. See R. Sharpe, 'Anselm as Author: Publishing in the Late Eleventh Century', Journal of Medieval Latin 19 (2009), 1-87.
} 
indicative of his having used any version of the text earlier than Version 4, which Greenway has conclusively shown to have been finished around 1146-7 and which arrived at Le Bec not long afterwards. ${ }^{47}$ Indeed, it is entirely plausible that the copy of the $H A$ which Robert received in or shortly after 1147 could have featured a colophon dating to 1135 , even if its chronological narrative extended much further. This is, of course, precisely what we can see in the seven manuscripts which survive of Version 4: Cambridge Gg.ii.21; London, Lambeth Palace Library MS 327; Paris, Bibliothèque Nationale de France, MS lat. 6042; Paris, Bibliothèque Nationale de France, MS 6043; Rouen, Bibliothèque Municipale, MS 1177/U74; Rouen, Bibliothèque Municipale, MS 1178/U56; and Vatican, Bibliotheca Apostolica Vaticana, MS Reg. lat. 732). If this were the case, we would have a viable explanation as to why Robert still refers to the $H A$ as 'composed in 1135 ' in his Chronica, as this is precisely the date to which any colophon preserved in Version 4 would most likely have referred. Such an interpretation is supported by the fact that the earliest surviving copies of the Chronica can all be shown to feature narrative content from the $H A$ which could not possibly have been part of Version 3, but rather was added subsequently by Henry as part of Version 4. These include Henry's record of events occurring in England during the first half of the 1140s and, of course, the $E A W$. The discrepancy between the date of the colophon and the end of the HA's chronological narrative, upon which much of the Chronica's account of twelfth-century English history was based, ${ }^{48}$ thus seems to have gone unnoticed by Robert.

This inconsistency has not, however, escaped the attention of modern scholars, who have produced different explanations for it. Arguably the most prominent explanation was attempted by Dumville and reassessed by Greenway in her edition of the $H A$ :

If in 1139 Robert was given a copy of a version that ended in 1135, and used it in his chronicle, we have to suppose not only that the manuscript sent to Le Bec, and any copies of it, failed to survive, but also that Robert so thoroughly revised his chronicle after he received the 1146 version that the 1135 version cannot now be traced in any existing text. ${ }^{49}$

Greenway reveals some justified scepticism concerning such a version of events, despite admitting that Dumville 'put forward a strong argument' for it. ${ }^{50}$ Unfortunately, she does not explore this scepticism by investigating alternative explanations. Closer scrutiny nonetheless serves to support Greenway's suspicion as to the feasibility of Dumville's theory. The hypothesis that Robert, upon

\footnotetext{
${ }^{47} H A$, ed. Greenway, p. lxvi.

${ }^{48}$ Bates, 'Robert of Torigni', pp. 179-81.

${ }^{49} H A$, ed. Greenway, p. Ixxiii.

${ }^{50}$ Ibid. Also cf. Greenway, 'Manuscripts', p. 109: 'If Torigny did use a manuscript of the Historia that ended in 1135, we must suppose the existence not only of an 1135 text of the Historia that has left no manuscript descendants, but also of a version of Torigny's chronicle that was so revised after 1147 that it cannot now be traced in any surviving text. The latter possibility has been suggested and persuasively argued by Dr Dumville, and if the 1147 manuscript was not the first text of Henry's work to come to Bec, we would have an explanation of why the Bec library contents-list, inserted in the 1147 manuscript, describes it as 'nouiter edita ab Henrico Huntendunensi archidiacono'.
} 
receiving a more 'up-to-date' version of the $H A$ in the late 1140 s, went back to his Chronica and meticulously replaced all references to a previously received version throughout - so meticulously indeed 'that the 1135 version cannot now be traced in any existing text',$-{ }^{51}$ seems to owe much more to scholars' imagination than to documentary evidence. What is more, such an idea essentially represents a reflection of the work ethics of the modern historian, whose keenness to rely only on the most recent versions of publications cannot, however, be considered representative of medieval conceptions of writing history. It would appear, therefore, that much of the persuasiveness of Dumville's argument - as called into question by Greenway, albeit tentatively - hinges on another piece of evidence. It is to this piece of evidence that I shall now turn in the third and final section of my article, namely the twelfth-century library catalogue of Le Bec.

Le Bec's twelfth-century library catalogue and Leiden, Universiteitsbibliotheek MS BPL 20

In his study, Dumville draws our attention to a list of contents which can be shown to feature in no fewer than seven of the $H A$ 's surviving manuscript copies, ${ }^{52}$ usually inserted directly before the opening of the text and sequentially listing the main theme of each of its books. ${ }^{53}$ The earliest surviving example of this contents list is found in Cambridge, Gg.ii.21 (fig. 4), but it also occurs in four of the other manuscripts listed above as containing the 1135 colophon (Lambeth 327; Paris lat. 6043; Rouen 1177/U74; and Vatican Reg. lat. 732). The list in Cambridge, Gg.ii.21, f. 3r opens with a rubric: In hoc volumine continetur historia Anglorum noviter edita ab Henrico Huntendunensi archidiacono libri decem. Dumville considers the wording of this rubric, which he traces in Rouen $1177 / \mathrm{U} 74$, 'most unlike a normal introductory rubric'. According to him, it resembles 'nothing so much as a contents-list on the flyleaf of a twelfth-century Bec manuscript (reproducing an entry in the library-catalogue of Le Bec), or even of a Mont-Saint-Michel book of the second half of the twelfth century. ${ }^{54}$ The Le Bec manuscript referred to by Dumville is Leiden, Universiteitsbibliotheek MS BPL 20, Robert's personal copy of William of Jumièges GND, whereas the Mont-Saint-Michel manuscript can be identified with Avranches 159, Robert's working copy of the Chronica. ${ }^{55}$ The notion that this contents list was added to the HA in the scriptorium of Le Bec has since been re-

\footnotetext{
${ }^{51} H A$, ed. Greenway, p. Ixxiii.

${ }^{52}$ These are: Paris lat. 6043, ff. 1r-v; London Arundel 48, ff. 2r-v; Lambeth 327, f. 4r; Rouen 1177/U 74, f. 62r; Baltimore W 793, f. 1r; Vatican Reg. lat. 732, f. 1r; and Cambridge Gg.ii.21, f. 3r. My transcription here is based on my own reading of the Cambridge manuscript, which is commonly agreed to represent the earliest surviving copy of the $H A$ to feature the contents list (cf. $H A$, ed. Greenway, p. 833).

${ }^{53}$ Dumville, 'Early Text', pp. 10-13.

${ }^{54}$ Ibid., p. 10.

${ }^{55}$ I scrutinise the relationship between these two manuscripts in Pohl, 'Abbas qui et scriptor?'. Note, however, that these two manuscripts are not listed as containing the contents list in $H A$, ed. Greenway, p. 33.
} 
emphasised by Greenway, who tentatively yet convincingly reconstructs a common ancestor in the shape of text ' $\beta$ ', which also provides the archetype of Version 4 of the $H A .{ }^{56}$

What concrete evidence is there, then, to support Dumville's hypothesis that the rubric attached to the contents list in Cambridge Gg.ii.21, f. 3r and other copies of Version 4 reproduces an entry from the twelfth-century library catalogue of Le Bec? Generally speaking, I disagree that the wording of the rubric should be considered unusual of the period under consideration. In fact, it was by no means uncommon for twelfth-century historians and their copyists to preface works of historiography with similar rubrics - the surviving books from the library of Mont-Saint-Michel, where Robert continued his career after 1154 , suffice as a case in point. ${ }^{57}$ Also, the relationship which Dumville assumes between the $H A$ 's rubric and the entry in the Le Bec book list which survives in Avranches 159 can, upon closer examination, be defined much more accurately. First of all, it is important to note that Avranches 159 features not just one, but in fact two book lists on its flyleaves. The first lists the books bequeathed to Le Bec upon the death of Bishop Philip of Bayeux in 1163 (TITVLI LIBRORVM quos dedit philippus episcopus Baiocensis ecclesiae Becci, f. 1v), whereas the second contains the holdings from the monastery's armarium (TITULI LIBRORVM BECCENSIS ALMARII, ff. 2r-3r). The HA is recorded only in the second of these two lists, that on f. $3 \mathrm{r}$ (In alio. Historia Henrici, de gente Anglorum, lib. X) ${ }^{58}$ Scholars, myself included, have produced evidence to suggest that the two lists in Avranches 159, ff. 1v-3r were drawn up at Robert's personal behest, possibly during the mid-1160s. ${ }^{59}$ In fact, I have identified Robert's hand as making interlinear corrections to both book lists whilst at Mont-Saint-Michel. What is more, Patricia Stirnemann has identified the manuscript of the HA listed in the catalogue of books which the monks of Le Bec inherited from Philip of Bayeux with Paris lat. 6042, and my own palaeographical analysis has shown that this manuscript, too, contains corrections made in Robert's own hand. ${ }^{60}$ Could it be, therefore, that the rubric which survives in Paris lat. 6042 and, a little earlier, in Cambridge Gg.ii.21 was originally inserted into the HA by Robert himself at Le Bec as part of the now-lost archetype ' $\beta$ '?

\footnotetext{
${ }^{56}$ Ibid., pp. 833-5.

${ }^{57}$ During my studies in the Bibliothèque Municipale d'Avranches, I have identified similar rubrics in, for example, Avranches, Bibliothèque Municipale MS 68 and Avranches, Bibliothèque Municipale MS 241. Also cf. the manuscripts listed by J. Lair and L. Delisle, 'Matériaux pour l'édition de Guillaume de Jumièges préparée par Jules Lair, membre de l'Institut, préface de Leopold Delisle, membre de l'Institut', Bibliothèque de l'école des chartes, 71 (1910), 481-526. On the medieval library of Mont-Saint-Michel in general, see particularly G. Nortier, 'La Bibliothèque de l'abbaye du Mont Saint-Michel: Les bibliothèques médiévales des abbayes bénédictines de Normandie', Revue Mabillon 47 (1957), 135-68.

${ }^{58}$ There is, however, a similar entry in the list on f. 1v, line 44 (In alio historia Henrici de Anglia et liber Bede minor de tempore et de natura rerum), which, moreover, seems to have been amended in Robert's own hand. Both lists have been transcribed on the basis of Avranches 159, ff. 1v-3v by M. F. Ravaisson, Rapport au ministre de l'instruction publique sur les bibliothèques des départments de l'Ouest (Paris, 1841), 375-95, at $\mathrm{p}$. 387. They were later reproduced in J. P. Migne, Patrologia Latina, 217 vols. (Paris, 1841-65), CL, 770-82, at p. 777. Also cf. G. Becker, Catalogi bibliothecarum Antiqui (Bonn, 1885), pp. 199-202, 257-66; Nortier, Bibliothèques, pp. 39-40.

${ }^{59}$ Rouse and Rouse, 'Potens', p. 323.

${ }^{60}$ Ibid., p. 338; Stirnemann, 'Bibliophiles', p. 140; Pohl, 'Abbas qui et scriptor?'.
} 
The bibliographic entries in the two book lists from Le Bec on the flyleaves of Avranches 159 all follow the same format. They begin with either 'in one/in a single volume...' ([In] uno volumine...), 'in one/in a single [volume]' (In uno...), 'in the same [volume]' (In eodem...) or 'in another [volume]' (In alio...). At no point do we encounter any example to match precisely the wording of the HA's rubric, which, as we have seen, reads 'in this volume' (In hoc volumine...). Indeed, the use of the demonstrative pronoun hoc - rather than uno, eodem or alio - strongly suggests that the rubric first attested in the table of contents for Cambridge Gg.ii.21, f. 3r was originally designed as a navigation aid for use within the manuscript itself, rather than as part of a larger catalogue. It seems unlikely, therefore, that the rubric's wording represents a reproduction of the corresponding book lists in Avranches 159, especially considering that these lists were not drawn up until 1163, the year of Philip's death. If anything, the exact opposite seems to be more likely, with the catalogue reproducing the table of contents as found in Le Bec's copy of the $H A$, rather than the other way around. Such a relationship also seems to hold true with regard to Leiden BPL $20{ }^{61}$ On the manuscript's heavily-damaged flyleaf (f. 1v), we find a similar list of contents (fig. 5). ${ }^{62}$ Amongst other texts, Leiden BPL 20 contains Robert's working copy of the GND, which he appears to have finished whilst still at Le Bec. ${ }^{63}$ Like Paris lat. 6042, Leiden BPL 20 also occurs in one of the book lists in Avranches 159. This time, however, the manuscript corresponds to an entry in the list of books formerly belonging to the Bishop of Bayeux, rather than to the armarium, copied on $\mathrm{f} .1 \mathrm{v}$ (In uno volumine historie Normannorum lib. VII. videlicet ab adventu Hastingi in regnum Francorum usque ad mortem primi Henrici regis Anglorum et ducis Normannorum).

Once again, the wording of the initial line differs slightly between Leiden BPL 20 and the corresponding entry in Avranches 159. Whereas Leiden BPL 20 reads In hoc volumine ista continentur, Avranches 159 has In uno volumine in the same place. As the rest of the entry is virtually identical, it seems very likely that whoever drew up the original catalogue at Le Bec and listed Leiden BPL 20 amongst its holdings reproduced the list of contents which he found conveniently summarised and ready to be copied on the flyleaf of the manuscript. Arguing for the opposite makes little sense. That this is plausible is further suggested by a small marginal gloss which features in Cambridge Gg.ii.21, f. 3r (fig. 4). This gloss, which seems to have gone unnoticed by scholars, reads: 'Included

\footnotetext{
${ }^{61}$ A formidable up-to-date description of the manuscript including a summary of the latest state of research can be found in the so far unpublished PhD dissertation by Jaakko Tahkokallio, 'Monks, Clerks, and King Arthur: Reading Geoffrey of Monmouth in the Twelfth and Thirteenth Centuries' (University of Helsinki, Dissertation, 2013), pp. 171-72.

${ }^{62}$ My own transcription of this contents list reads: In hoc vol[umine ista con]tinentur [...] historiae [orma]norum libri octo vide[licet] ab adventu hastingi in regnum francorum usque ad mortem primi henrici regis anglorum et ducis normannorum. Item vita caroli magni imperatoris romanorum et regis francorum. Item vita alexandri magni regis macedonum. Item epistola eiusdem de situ indiae ab aristotelem magistrum suum. Item abbreviatio gestorum regum franciae ab egressione eorum a sicambria usque ad principium regni ludovici iunioris regis francorum et ducis aquitanorum. Item hystoriarum de regibus maioris britanniae usque ad adventum anglorum in eandem insulam libri xii. in quorum septimo continentur prophetiae mellini non silvestris sed alterius id est mellini ambrosii. Item exceptiones ex libro gildae sapientis historiographi britonum quem composuit de vastatione suae gentis et de mirabilibus britanniae.

${ }^{63} G N D$, ed. van Houts, I, cix. Also cf. Dumville, 'Early Text', pp. 2-4.
} 
here in brief is a summary of the entire work which follows' (Hic comprehenditur breviter summa totius sequentis operis). Inserted at the same time as the main text, and by the same hand which copied the rest of the $H A$, the gloss is evidently meant to provide an internal navigation aid, rather than to refer to a more comprehensive catalogue. To make matters even more complicated, there still is no consensus amongst scholars as to the precise date when the book lists of Le Bec were first drawn up. ${ }^{64}$ The earliest (and only) manuscript copy is that contained amongst the flyleaves of Avranches 159, which was written at Mont-Saint-Michel during the mid-1160s (definitely after 1163). Geneviève Nortier suggests that Avranches 159, ff. 1v-3r, in turn, were copied directly from an exemplar kept at Le Bec, which, however, does not survive today. ${ }^{65}$ Whilst this is of course perfectly possible, the absence of such an exemplar leaves the date of Avranches 159 as the only definite terminus ante quem.

That the $H A$ is listed in Avranches 159, f. $3 \mathrm{r}$ as consisting of ten books (libri decem) unfortunately provides no conclusive dating evidence either, given that Henry had started working on the HA's Tenth Book as early as c.1140 as part of Version 3, with the narrative terminating in 1139. He then subsequently expanded the chronology of Book Ten over the course of one and a half decades, first to 1146 (Version 4), then to 1149 (Version 5), and, finally, to 1154 (Version 6). ${ }^{66} \mathrm{As}$ mentioned earlier, the first version of the $H A$ which can be proven conclusively to have been received at Le Bec is Version 4, and there is good reason to believe that this manuscript might in fact have been the archetype ' $\beta$ ' from which Paris lat. 6042, Cambridge Gg.ii.21 and the four other copies of version 4 featuring both the table of contents and the 1135 colophon derive. Based on the formulation In hoc volumine continetur historia Anglorum noviter edita ab Henrico Huntendunensi archidiacono libri decem (Cambridge Gg.ii.21, f. 3r), it has been suggested that Robert, or whoever drew up the Bec library catalogue at his behest, intended to emphasise that the $H A$ was now available at Le Bec in a more recent version, which updated and, supposedly, replaced the one previously kept there. ${ }^{67}$ Such an interpretation turns fundamentally on the way in which we choose to interpret the Latin words noviter edita, which have previously been translated as 'edited again/anew'. This has led Greenway to suggest that '[i]f the fourth (1146) version of the $H A$ was not the first text to come to Le Bec, we would have

\footnotetext{
${ }^{64}$ Unfortunately, Dumville throughout his article keeps referring forward to one 'appendix II', in which he promises to provide a more conclusive discussion on the content and date of the Le Bec catalogue (see, for example, Dumville, 'Early Text', p. 3 and p. 30); however, the article does not feature such an appendix, and neither does the update which Dumville provided in Arthurian Literature 4 (1984), 164-71. Curiously enough, in the reprint of the entire article in D. Dumville, Histories and Pseudo-Histories of the Insular Middle Ages, Variorum Collected Studies 316 (Ashgate, 1990), pp. 1-36 [i.e., no. XIV], all the references to said appendix have disappeared entirely. Instead, Dumville here refers the reader directly to Avranches 159 and a subsequent 'Mont-Saint Michel copy', which, however, he does not identify in any further detail.

${ }^{65}$ Nortier, Bibliothèques, pp. 40-1.

${ }^{66}$ See the table provided in $H A$, ed. Greenway, pp. 1xviii-ix.

${ }^{67}$ See Dumville, 'Early Text', pp. 30-33; HA, ed. Greenway, p. 1xxiii.
} 
an explanation of why the contents list, inserted in the 1146 manuscript in the library of Le Bec describes it as 'nouiter edita' ${ }^{68}$ However, I do not believe such a translation to be compelling.

Indeed, a more fitting translation for noviter, in this context, might simply be 'recently/lately'. Similarly, I propose we translate edita (infin. edere), as 'published' - in the sense of making a written work public -, rather than 'edited'. ${ }^{69}$ The word 'to edit' implies a sense of reworking and revision which, to my mind, the rubric in Cambridge Gg.ii.21, f. 3r does not suggest. What is more, Robert himself actually uses the word edere in the sense of 'to publish' in his redaction of Henry's EAW. Here, again, the term is employed with particular reference to the $H A$. 'Having enquired about the series of the "History of the English Kings" which I had published' (de ordine hystoriae de regibus Anglorum a me editae me interrogaret) are the very words which Robert puts into Henry's mouth when relating their meeting at Le Bec in $1139 .^{70}$

\section{Conclusion}

It is now possible to give a more confident answer to the question as to when Robert first received a copy of the HA. Contrary to what scholars have often argued, the manuscript evidence reveals no compelling reason to suggest that a manuscript of Henry's 'History of the English' was received at Le Bec any time before the mid- to late 1140s. The idea that Henry brought with him a working copy of the $H A$ when visiting Le Bec in 1139 is wholly and essentially based on Robert's later redaction of the $E A W$. Henry's original and more contemporary record of the events of 1139 does not support this hypothesis, and neither does the codicological evidence.

It seems safe to assume that when Henry came to Le Bec in 1139 , he was presented with a copy of Geoffrey's $H R B$ which was kept at, and perhaps owned by, the abbey's library. Whether or not Robert played any major part in these events cannot be known with certainty, but it is not unlikely given his familiarity with the monastery's book collection. If it was indeed Robert who handed Henry the manuscript of the $H R B$, it seems very likely that the two likeminded historians would have engaged in conversation, so Henry could well have told Robert about his current project, the $H A$. There is really no reason to challenge Bates' suggestion that by the late 1130 s, Robert, whilst just putting the final touches to his redaction of the $G N D$, might already have had his mind set on his next and even more ambitious endeavour: the composition of the Chronica. ${ }^{71}$ Henry might even have promised Robert that he would send over a copy of the $H A$ to Le Bec at a later stage, both to assist Robert in writing his Chronica and to show his gratitude for being granted access to Geoffrey's $H R B$. However, in 1139 no copy of Henry's work was exchanged. It was not before second half of the

\footnotetext{
${ }^{68} H A$, ed. Greenway, p. lxxiii.

${ }^{69}$ Such a translation of edere as 'to publish' is also suggested by Sharpe, 'Anselm as Author', p. 1.

${ }^{70}$ Chronique, ed. Delisle, I, 97.

${ }^{71}$ Bates, 'Robert of Torigni', pp. 177-8.
} 
1140 s, most likely in or shortly after 1147 , that Robert finally received a manuscript of the $H A$ 's Version 4, less than a decade before he would leave the community at Le Bec to become abbot at Mont-Saint-Michel. It was this manuscript which made its way into in the library catalogue.

Patently, neither Robert himself nor later generations of historians were interested in relating the story of the HA's acquisition in this sober and, by comparison, fairly unexciting manner. Robert was the first to embellish the events of 1139 and, in his redaction of the EAW, present Henry's visit as a 'professional' meeting between colleagues. The picture he draws is that of two fellow historians, who - in veneration of each other's erudition and expertise - gladly agree to exchange knowledge concerning the subject matter of their respective works. Rather than simply copying Henry's letter to Warin, Robert chooses to emphasise his own importance in the matter. Whether or not this reflects a genuine recollection of how Robert remembered things, or whether it was a product of his own wishful thinking, is difficult to know for sure. Things may have happened how Robert tells us; or perhaps his version of events owes much to a sense of self-importance and entitlement which Robert developed in the course of his monastic career, for example, in the context of being made prior of Le Bec. When Robert finally received a copy of the HA's Version 4 during the second half of the 1140s, he probably was reminded of Henry's visit a decade earlier - after all, he would have witnessed it, even if he had not played as important a part as he claims. When describing the events of 1139 in the pages of his Chronica, Robert may have opted to relate things, perhaps not exactly how they had happened, but rather how he believed they should have happened, with the benefit of hindsight.

Why does this matter, then? What are the implications of this result for the study of twelfthcentury historiography and the ways in which its protagonists interfered with each other and, by extension, each other's works? First of all, the nature of Robert's engagement with Henry's HA serves to show that 'intertextuality' - a term frequently used in modern studies on medieval textual and literary culture - in this case should probably be conceived of primarily as a practical, rather than a theoretical, phenomenon. It is true that twelfth-century writers such as Robert and Henry were rarely if ever working in perfect isolation; rather, these writers usually acted within wider fields of textual production and manuscript dissemination, often participating in larger socio-literary communities. What we sometimes seem to forget, living in an age which has witnessed the introduction of electronic publications and open-access text repositories on an international scale, is that during the twelfth century the precise chronology of textual transmission and acquisition could effect a significant difference, both for the writer and his/her audience. Even or perhaps especially in cases where the surviving evidence allows us to differentiate with confidence between individual years rather than decades, intertextuality becomes inseparably intertwined with, and fundamentally dependent on, the logistics which allowed individual manuscripts to travel between different institutions. Questions of accessibility and availability are thus key to medieval intertextual practice, much more crucially so than they sometimes seem to be to modern intertextual theory, where access is, or at least is often 
assumed to be, generally (if not universally) available. As Bates has argued, Robert might well have made plans to write a history of England as part of his Chronica well before Henry first came to visit Le Bec in 1139, and apparently he did try to pursue these plans further during the mid-1140s. However, until Robert finally received a copy of the $H A$ in 1147 or so, he inevitably had to rely on other materials more readily available to him and his institution at the time. That Robert tells his readers differently in his modified version of the $E A W$, in which he claims to have received the $H A$ as early as 1139 , demonstrably signifies an ex post facto attempt to compensate for, and skilfully gloss over, this prolonged lack of accessibility.

The fact that Robert in his Chronica creates an illusion of Henry as having provided him with a copy of the $H A$ about ten years earlier than was actually the case reveals that, to him at least, chronology did in fact matter. Yet, I believe the modified version of events which we find in the Chronica to be a witness to more than just personal gratification on the part of its author. Rather, it seems to suggest that Robert, in artificially emphasising the importance of the $H A$ for the writing of his Chronica during the late 1130s and early 1140s, was assuming that this altered chronology of composition would matter to his prospective audience, too. As the prologues of many historiographical works from the period show, naming one's textual authorities and pointing out intertextual relationships - sometimes explicitly, often implicitly - was a common technique amongst the historians of the Anglo-Norman world. ${ }^{72}$ With written authorities frequently being supplemented by oral testimony, especially for the more recent events covered in a work of contemporary history such as in the later chapters of the Chronica, being able to claim personal acquaintance with another historian of great repute was an opportunity not to be missed, especially if it could be engineered so that the reader believed the manuscripts to have been exchanged first-hand. Robert's retelling of the events which supposedly led up to his acquisition of the $H A$ should therefore not be considered an attempt to substitute fact with fiction, let alone a deliberate forgery. Rather, it should be taken as evidence for the various ways in which historians of this period consciously sought to endow their works with authority through intertextuality, both on a textual and, where possible, personal level.

\footnotetext{
${ }^{72}$ See the examples provided by A. Gransden, 'Prologues in the Historiography of Twelfth-Century England', Legends, Tradition and History in Medieval England (London, 1992), pp. 125-152; A. Gransden, Historical Writing in England (London, 1974).
} 


\section{Appendix:}

The dated colophons in the manuscripts of the $H A$

\begin{tabular}{|c|c|c|c|c|}
\hline Manuscript & Date & Version of $\mathrm{HA}$ & End of narrative* & Colophon \\
\hline Blackburn 26 & s. $\mathrm{xii}^{\mathrm{ex}}$ & 5 & 1149 & 1145 (f. 12r) \\
\hline Cambridge CCC 280 & S. xiii $^{\text {med-ex }}$ & 3 & 1138 & 1135 (f. 6r) \\
\hline Cambridge Dd.i.17 & s. xiv $^{\text {ex }}$ & 6 & 1154 & 1145 (f. $6 r$ ) \\
\hline Cambridge Gg.ii.21** & s. xii ${ }^{\text {med }}$ & 4 & 1146 & 1135 (f. 3r) \\
\hline Cambridge Ii.ii.3 & S. xiii $^{\text {in }}$ & 6 & 1154 & 1135 (f. 147r) \\
\hline Cambridge SJC 184 & s. xiv $^{\text {ex }}$ & 5 & 1149 & 1146 (f. 120r) \\
\hline Cambridge TC R.5.42 & s. $\operatorname{xiv}^{\text {in }}$ & 5 & 1149 & 1145 (f. 1r) \\
\hline Edinburgh 33.5.2 & s. xii $^{\text {med }}$ & 6 & 1154 & 1145 (f. 1r) \\
\hline Lambeth 118 & s. $\mathrm{xii}^{\mathrm{ex}}$ & 5 & 1149 & 1145 (f. 1r) \\
\hline Lambeth 179 & s. xiii $^{\text {in }}$ & 5 & 1149 & 1145 (f. 1r) \\
\hline Lambeth $327 * *$ & S. xii $^{\text {med-ex }}$ & 4 & 1146 & 1135 (f. 4v) \\
\hline London Add 24061 & S. $\operatorname{xiv}^{\text {in }}$ & 3 & 1138 & 1135 (f. 1r) \\
\hline London Arundel 46 & s. XV & 6 & 1154 & 1145 (f. 1r) \\
\hline London Egerton 3668 & s. xii ${ }^{\text {med }}$ & 3 & 1138 & 1135 (f. 1v) \\
\hline London Grays Inn 9 & s. xiv & 5 & 1149 & 1145 (f. 88r) \\
\hline London Royal 13 A xviii & s. $x_{i v}^{\text {in }}$ & 5 & 1149 & 1145 (f. 77r) \\
\hline London Royal 13 B vi & s. xiv $^{\text {med-ex }}$ & 6 & 1154 & 1145 (f. 2r) \\
\hline London Vespasian A xviii & s. xiii $^{\text {med }}$ & 5 & 1149 & 1145 (f. 3r) \\
\hline Oxford 521 & s. xiv $^{\text {ex }}$ & 6 & 1154 & 1145 (f. 1v) \\
\hline Paris lat. 10185 & s. $\mathrm{xii}^{\mathrm{ex}}$ & 5 & 1149 & 1145 (f. 1r) \\
\hline Paris lat. 6042 & S. xii $^{\text {med }}$ & 4 & 1146 & 1135 (f. 3r) \\
\hline Paris lat. 6043** & S. $x v i^{\text {med-ex }}$ & 4 & 1146 & 1135 (f. 1v) \\
\hline Rouen 1177/U74** & S. $\mathbf{x i i}^{\mathrm{ex}}$ & 4 & 1146 & 1135 (f. 62r) \\
\hline Rouen 1178/U56 & S. xvi & 4 & 1146 & 1135 (f. 1r) \\
\hline Vatican Reg. lat. 587 & s. xvii & 5 & 1149 & 1145 (f. 3r) \\
\hline Vatican Reg. lat. $732 * *$ & S. Xvii & 4 & 1146 & 1135 (f. 1v) \\
\hline
\end{tabular}

* Some of the manuscripts only contain fragments of the $H A$, in which case the end of the chronological narrative is projected based on the text which survives in related manuscripts of the same version.

** Also contains the list of contents (In hoc volumine [...]). 


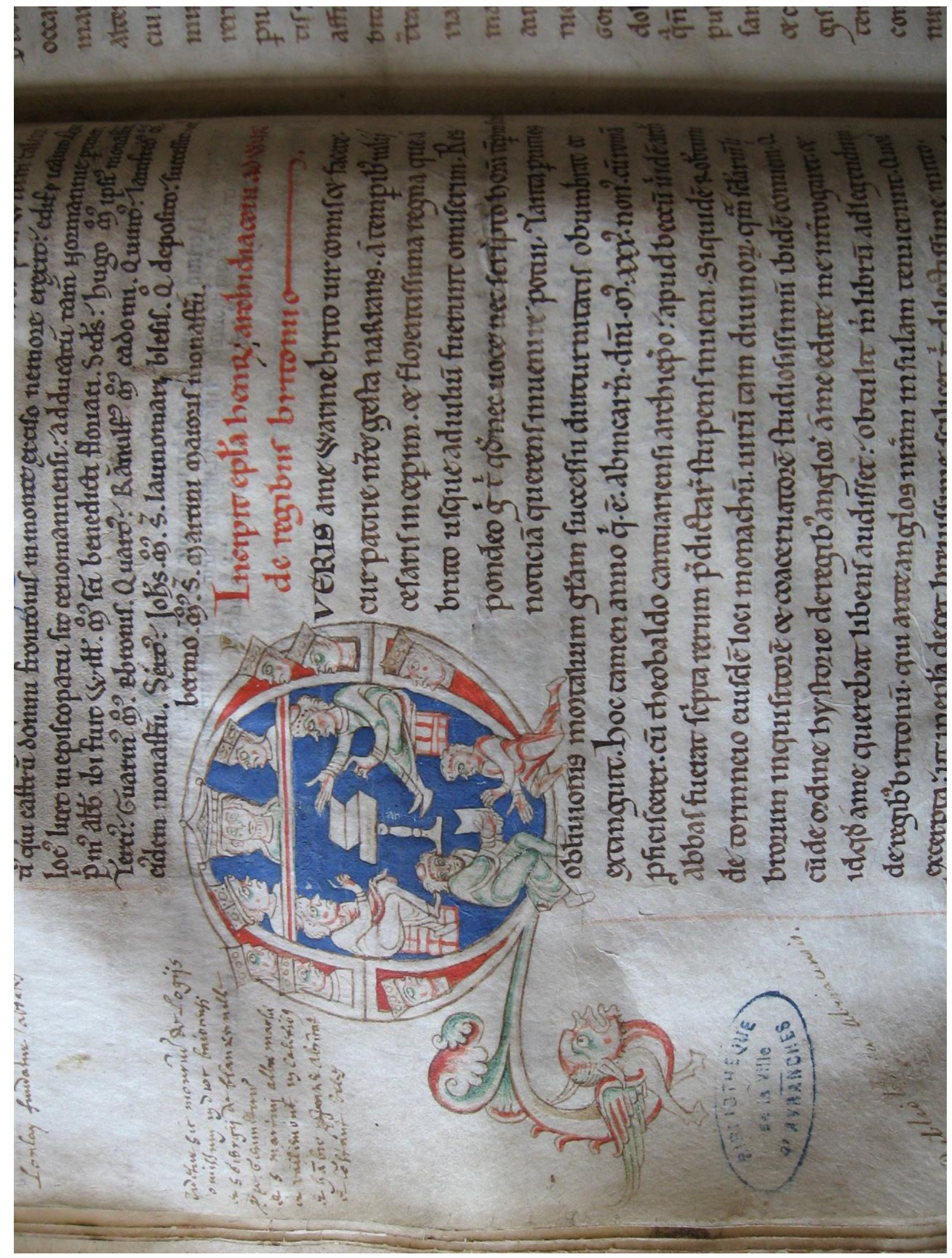

Fig. 1: Avranches, Bibliothèque Municipale MS 159, f. 174v. 


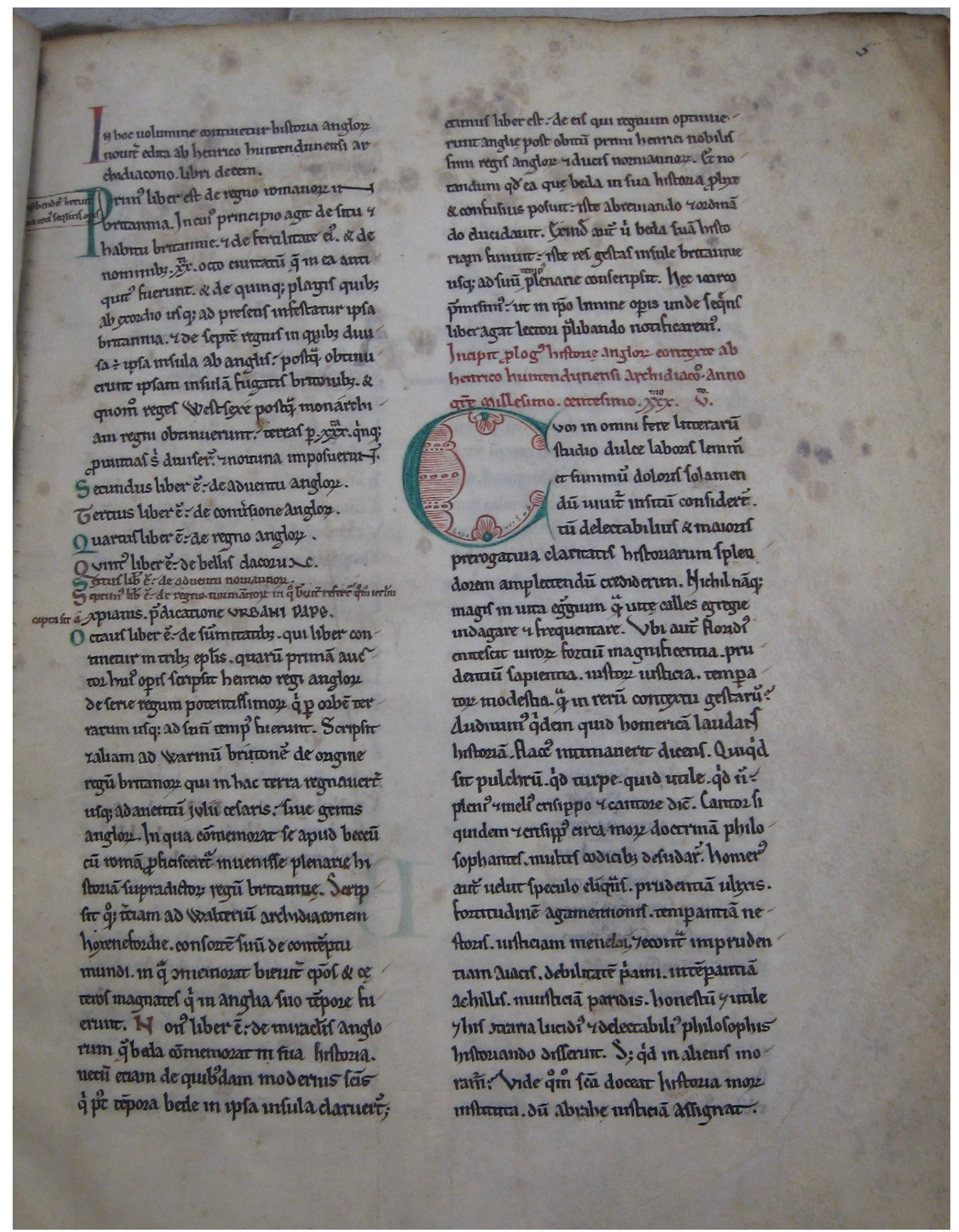

Fig. 2: Cambridge, University Library MS Gg.ii.21, f. 3r. 
Pohl, 23

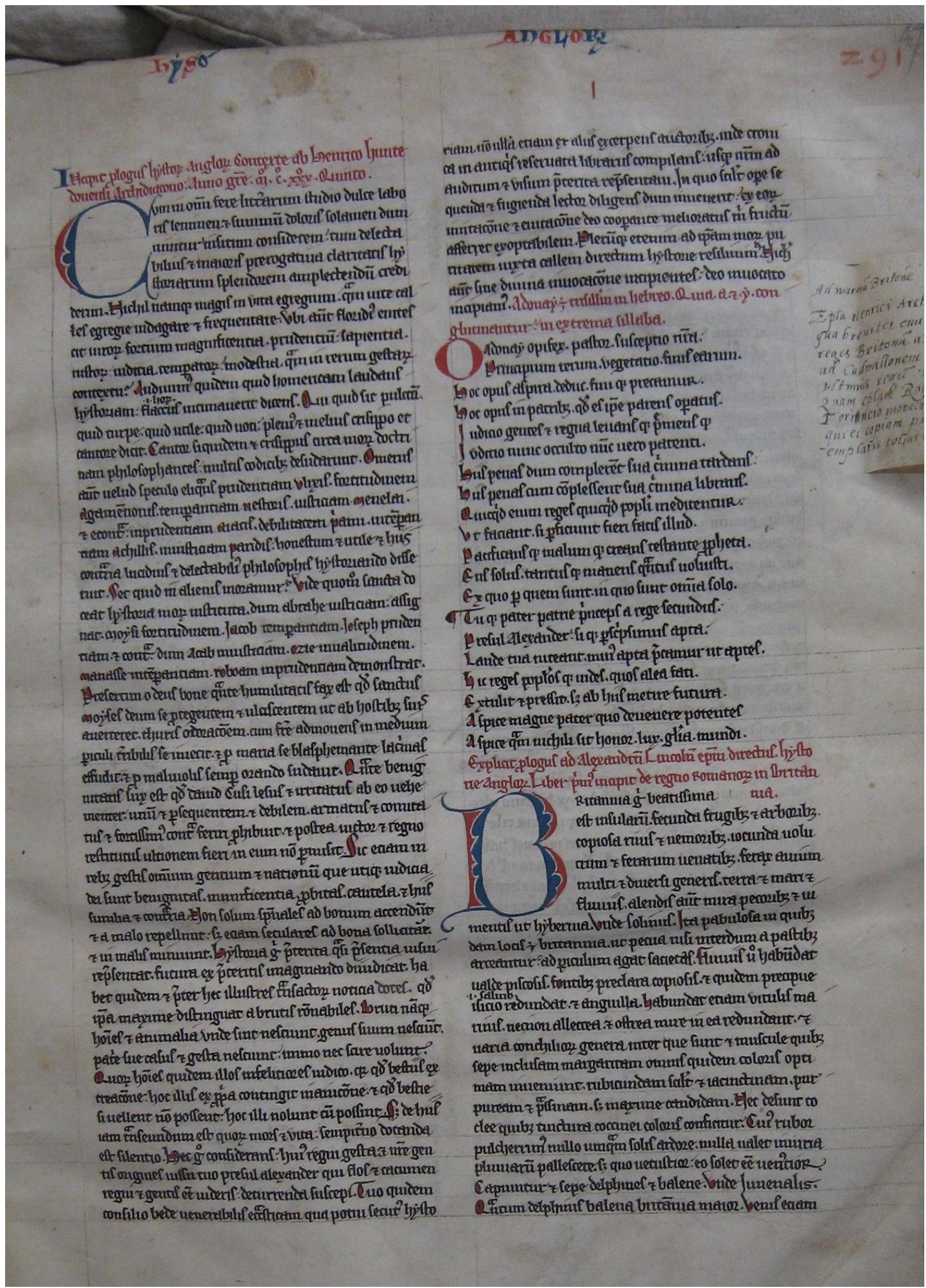

Fig. 4: Cambridge, University Library MS Ii.ii.3, f. 147r. 


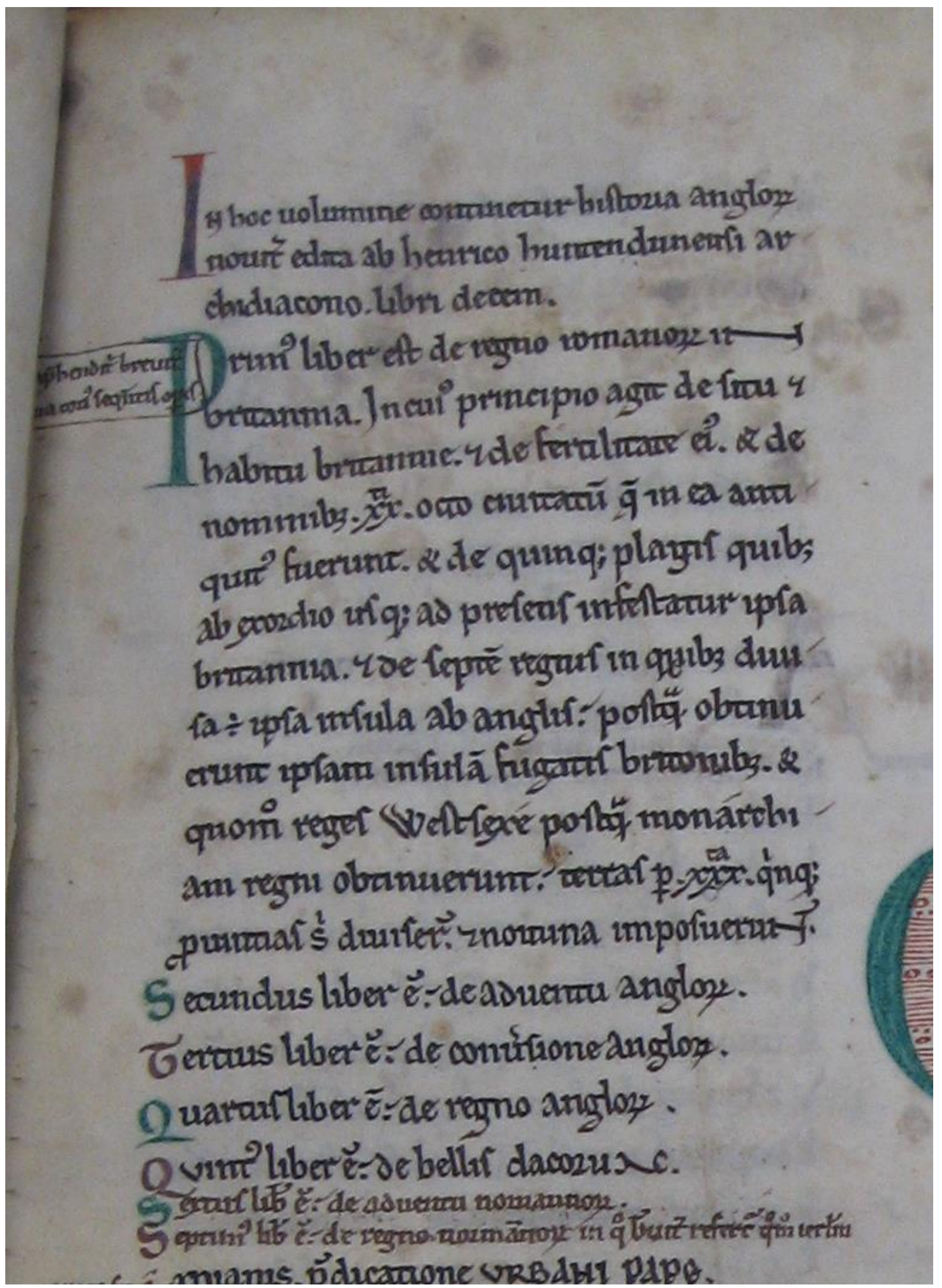

Fig. 4: Cambridge, University Library MS Gg.ii.21, f. 3r (detail). 


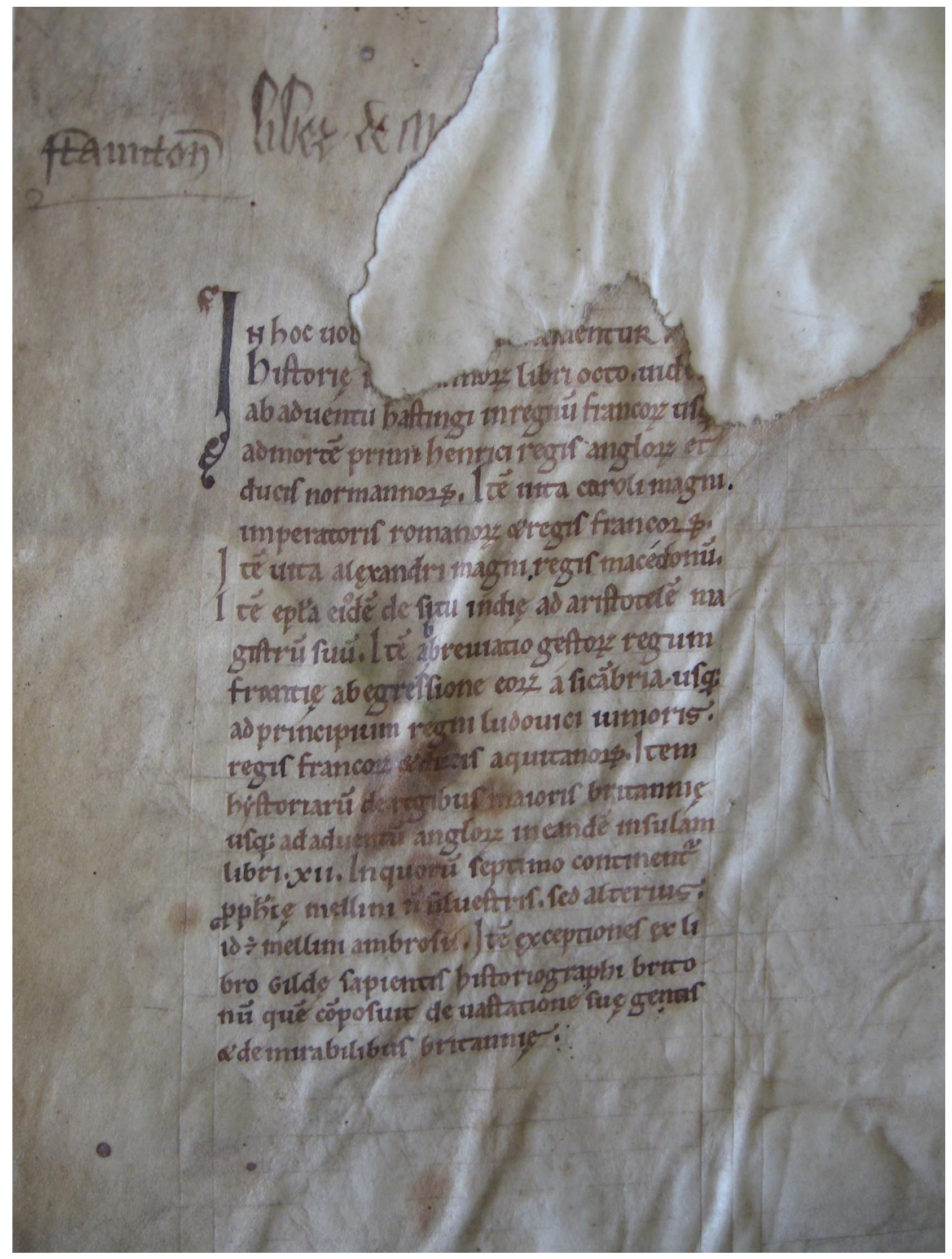

Fig. 5: Leiden, Universiteisbibliotheek MS BPL 20, f. 1v. 